Whitewashing Britain 



\title{
WHITEWASHING BRITAIN
}

Race and Citizenship in the Postwar Era

\author{
Kathleen Paul
}

Cornell University Press

Ithaca and London 


\section{Copyright (C) 1997 by Cornell University}

All rights reserved. Except for brief quotations in a review, this book, or parts thereof, must not be reproduced in any form without permission in writing from the publisher. For information, address Cornell University Press, Sage House, 512 East State Street, Ithaca, New York 148 so.

First published 1997 by Cornell University Press

First printing, Cornell Paperbacks, 1997

\section{Library of Congress Cataloging-in-Publication Data}

Paul, Kathleen, 1964-

Whitewashing Britain : race and citizenship in the postwar era /

Kathleen Paul.

p. $\mathrm{cm}$.

Includes bibliographical references and index.

ISBN-13: 978-0-8014-8440-7 (pbk. : alk. paper)

ISBN-ro: 0-8014-8440-5 (pbk.: alk. paper)

1. Great Britain -Emigration and immigration-Government policy

2. Citizenship-Great Britain. 3. Racism-Great Britain. 4. Great

Britain-Politics and government-1945-1964. I. Title.

$\mathrm{JV}_{7633 . P 38} \quad 1997$

$325.4 \mathrm{I}^{\prime} 09^{\prime} 045-\mathrm{dc} 2 \mathrm{I}$

$97-5410$

Cornell University Press strives to use environmentally responsible suppliers and materials to the fullest extent possible in the publishing of its books. Such materials include vegetable-based, low-VOC inks and acid-free papers that are recycled, totally chlorine-free, or partly composed of nonwood fibers. For further information, visit our website at www.cornellpress.cornell.edu.

$\begin{array}{llllllll}\text { Paperback printing } & \text { IO } & 9 & 8 & 7 & 6 & 5 & 4\end{array}$ 
For my Dad 
